\title{
Survival Rate and Growth Response of Humpback Grouper Seeds (Cromileptes altivelis) on Acclimatization to the Freshwater
}

\author{
Sunaryo $^{1}$, Marmi ${ }^{1}$, and Sonny Kristianto ${ }^{1}$ \\ ${ }^{1}$ Study Program of Biology Education, Faculty of Language and Science Universitas Wijaya \\ Kusuma Surabaya \\ "email: sunaryohasan@yahoo.co.id
}

\section{Article Info}

Key Word :

Survival Rate

Growth

Humpback grouper

Seed

Acclimatization

Fresh Water

Article history:

Submitssion: 11-12-2018

Accepted: 14-02-2019

\begin{abstract}
Successful marine biota cultivated in freshwater fish is whitefish, tiger shrimp and vannamei shrimp. While humpback grouper (Cromileptes altivelis) prospecting for export market have never been tried. This research would like to know the influence of acclimatization of humpback grouper seed into fresh water towards the survival rate and growth response. It uses complete random design five tipes of treatment and four times replication using seed samples with long range $12 \mathrm{~cm}$, weight 22 gram. Acclimatization of habitat in salinity 30 ppt to 4 ppt. The treatment is $A_{0}$ with the decrease in salinity 0,0 ppt/day (control), $A_{0,5}\left(0.5 \mathrm{ppt} /\right.$ day), $A_{1}$ (1 ppt/day), $A_{1, .5}(1.5$ ppt/day), and $A_{2}$ (2 ppt/day). Data of survival rate were analyzed by $t$ test $(P \leq 0.05)$, the result showed the decrease in salinity $0.5 \mathrm{ppt/day} 35 \%$ was significant different from control of $92.5 \%$, but it was higher compared to three other treatments $\left(A_{1}, A_{1.5}\right.$ and $\left.A_{2}\right)$ which were death before they reached 4 ppt. While the growth rate data were analyzed with Anova followed by Duncan test $(P \leq 0.05)$, the result showed $A_{0.5} 0.60 \%$ was not significant different from control of $0.61 \%$ but it was significant different (fastest) compared to three other treatments $\left(A_{1}, A_{1.5}\right.$ and $\left.A_{2}\right)$. The conclusion is humpback grouper can be cultivated in brackish water with 4 ppt (mesohalin) through acclimatization with the decrease in salinity $0.5 \mathrm{ppt} /$ day.
\end{abstract}

Copyright @ 20XY Universitas Islam Negeri Raden Fatah Palembang. All Right Reserved

\section{Introduction}

The cultivation of marine fish to the pond of fresh water has long been conducted by people in Lamongan and Gresik East Java. It was started by whitefish, tiger shrimp and vannamei shrimp. The cultivation is classified unique because it is far from the beach and uses fresh water coming from rainy water. They acclimate tiger shrimp seeds into fresh water with the decrease in salinity 3-4 ppt/day (Maryadi 2008). From the success of the cultivation, there is the desire to cultivate sea fish prospecting the exsport market. It is humpback grouper (Cromileptes altivelis) which is alive around IDR 600.000,-/Kg. But up to now, no one has been trying to do acclimatization of the humpback grouper.

Humpback Grouper classified stenohalin is fish living in certain aquatic, which has low tolerance towards changes 
in salinity. It is different with Euryhaline fish, that is migration fish, which has high tolerance towards changes in salinity (Willmer, et al, 2004). The successful cultivation of whitefish and shrimp by people in Gresik and Lamongan is involved in migration fish, even whitefish classified euryhaline acclimates to fresh water quickly. On the other hand, stenohalin fish must be slower due to the displacement of marine fish to fresh water suddenly can cause stress and as a result of disturbance of osmoregulation process (Irianto, 2005).

The current report has not been found the cultivation of humpback grouper into brackish water. The research would like to know survival rate and growth of humpback grouper seeds acclimating into fresh water with the decrease in salinity differently, namely $0.00 \mathrm{ppt} / \mathrm{day}$ (control), $0.5 \mathrm{ppt} / \mathrm{day}, 1 \mathrm{ppt} / \mathrm{day}, 1.5 / \mathrm{ppt} / \mathrm{day}$, and 2 $\mathrm{ppt} /$ day. It is hoped the seeds obtained can be alive in brackish water habitat.

\section{Materials and Methods}

The research used experimental research, with complete random design using five tipes of treatment and four times replications and each replication consisted of ten (10) humpback grouper seeds with a range of long size was $12 \mathrm{~cm}$, weight 22 gram. The treatments $\mathrm{A}_{0}$ was as control (the decrease in salinity $0 \mathrm{ppt} /$ day), $\mathrm{A}_{0.5}$ (the decrease in salinity $0.5 \mathrm{ppt} /$ day), $\mathrm{A} 1$ ( the decrease in salinity $1 \mathrm{ppt} /$ day), $\mathrm{A}_{1.5}$ (the decrease in salinity $1.5 \mathrm{ppt} /$ day), and $\mathrm{A}_{2}$ (the decrease in salinity $2 \mathrm{ppt} /$ day). The decrease in salinity was carried out by dropping fresh water through infuse set (infusion for patients in the hospital) that set it velocity. Acclimatization of habitat $30 \mathrm{ppt}$ was decreased to $4 \mathrm{ppt}$.

\section{Tools and Materials}

The equipments used were aquarium, aerator, filter, infuse set, refractometer, $\mathrm{pH}$ meters, DO meters. While the materials were sea water, aquades, humpback grouper seeds, and feed.

\section{Procedures of Experience}

1. Aquarium was filled sea water in salinity $30 \mathrm{ppt}$ as much as 25 liter, then it was flowed by oxygen for 24 hours. Infuse set was installed on fresh water reservoire to drop freshwater, seeds inside it. Aerator was constantly switched on during the research.

2. The seeds were left without doing treatment for 2 days for acclimatization and cleaning is still carried out every day. Feeding $3 \mathrm{x}$ a day at 06.00, 12.00 and 18.00 ,

3. Calculating volume of aquades which added to decrease in salinity in accordance with the formula velocity V1. N1 = V2. N2.

$$
\begin{aligned}
& \text { V1 }=\text { initial volume of water } \\
& \text { V2 }=\text { volume of water in the Add } \\
& \text { N1 }=\text { initial salinity } \\
& \text { N2 }=\text { desired salinity }
\end{aligned}
$$

4. The decrease in salinity was started at 07.00 WIB with the addition of drops by drops of aquades for 24 hours through infuse set. After 07.00 p.m. till next day the aquarium water which had decreased in salinity disposed a number of the volume that was added, and so on. The decrease in salinity was halted when it had reached 4 ppt.

5. Observation on all the treatments $\left(\mathrm{A}_{0,5}, \mathrm{~A}_{1}\right.$, $\mathrm{A}_{1.5}, \mathrm{~A}_{2}$ ) up to 14 days after doing the treatments, because the time of stress was already recovered.

\section{Variable Test}

1. Survival rate until 14 days after doing treatment (through stress recovery), with the formula refers to the study of Oktarina, (2009)

$$
\begin{aligned}
& \mathrm{SR}=\frac{N t}{N 0} \times 100 \% \\
& \mathrm{~N}_{\mathrm{t}}=\begin{array}{l}
\text { number of grouper seeds living until } \\
\text { today to } \mathrm{t}
\end{array} \\
& \mathrm{N}_{0}=\begin{array}{l}
\text { number of grouper seeds before } \\
\text { doing treatment }
\end{array}
\end{aligned}
$$

2 . The rate of growth is calculated by the formula refers to Efendi, (1979) in Agustina, et al. (2014)

$$
\mathrm{LPH}=\frac{\ln W t-\ln W 0}{t} \times 100 \%
$$

$\mathrm{Wt}=$ average weight of individual at $\mathrm{t}-$ time 
$\mathrm{W}_{0}=$ average weight of individual at initial time

$\mathrm{T}=$ maintenance time

\section{Data Analysis}

Data of survival rate were analyzed by $t$ test $(P \leq 0.05)$, while the growth rate data were analyzed with anova followed by Duncan test $(\mathrm{P} \leq 0.05)$ to know the efective treatment .

\section{Results And Discussions}

\section{A. Survival Rate}

Salinity rate on 10 days after treatment when the salinity of each treatment were $\mathrm{A}_{0}$ (control) remained $30 \mathrm{ppt}, \mathrm{A}_{0.5}$ wAs 25 ppt, $\mathrm{A}_{1}$ was $20 \mathrm{ppt}, \mathrm{A}_{1.5}$ was $15 \mathrm{ppt}$ and $\mathrm{A}_{2}$ was $10 \mathrm{ppt}$. These data were analyzed with Anova $(\mathrm{P} \leq 0.05)$, the result showed that there was significant difference between treatments. To know the was analyzed with Duncan test $(\mathrm{P} \leq 0.05)$, the result showed that there was the decrease in salinity 0.5 $\mathrm{ppt} / \mathrm{day}$ of the highest (equal to the control).

Table 1. Average of Survival Rate (\%) on 10 days of Treatment and the End of Treatment

\begin{tabular}{ccc}
\hline Treatment & $\begin{array}{c}\text { 10 days } \\
\text { Treatment }\end{array}$ & $\begin{array}{c}\text { End } \\
\text { Treatment }\end{array}$ \\
\hline A0 & $92,5 \pm 91,67^{\mathrm{a}}$ & $92,5 \pm 91,67$ \\
A0,5 & $92,5 \pm 25^{\mathrm{a}}$ & $35 \pm 166,67$ \\
A1 & $75 \pm 166,67^{\mathrm{b}}$ & 0 \\
A1.5 & $60 \pm 66,67^{\mathrm{c}}$ & 0 \\
A2 & $37,5 \pm 91,67^{\mathrm{d}}$ & 0 \\
\hline
\end{tabular}

On 10 days of treatment, control and treatment of the $\mathrm{A}_{0.5}$, the fish was already death, the cause of death was possible because of stress due to transportation that had not been recovered, Schreck explained (1981), in (Oktarina, 2009) time to recovery stress on fish was 10-14 days. While the death occurred in treatment $\mathrm{A}_{1}, \mathrm{~A}_{1.5}$ and $\mathrm{A}_{2}$ in which it was possible because they were not able to adapt to the lower salinity, It was stated by Subyakto and Cahyaningsih (2003) that on artificial seeding of humpback grouper, it was required in salinity 28-35 ppt.
Data at the end of treatment were only the result showed that there was significant difference from control. In fact the test statistic even without such data had already showed the treatment that the decrease in salinity $0.5 \mathrm{ppt} / \mathrm{day}$ that produced humpback grouper seeds that were able to survive at $4 \mathrm{ppt}$ in salinity. This was because of acclimatization was carried out by decreasing in salinity, that was 0.5 ppt/day. It was slower than the decrease in salinity was carried out by people in Lamongan when they acclimated tiger and vannamei shrimp seeds into freshwater, that was 3-4 ppt/day (Maryadi, 2008).

Salinity is the physical properties of water chemistry and it is a measure of the dissolved salt content, which determines the characteristics of the habitat of fish and other water organisms. Biochemical processes inside and outside the cells is affected by salinity (Kultz, 2015). The low survival rate figure of the humpback grouper seeds because it was different from the other types of fish such as grouper, tiger (Epinephelus fuscoguttatus) which their adaptation up to the top level $35 \mathrm{ppt}$ and lowest level 0 ppt (Anggoro, 2013). Changes in salinity caused stress that interfered the physiological homeostasis and other biological processes. Stenohaline fish was able to tolerate low salinity smaller than the euryhaline fish (Sakuragui, 2007 in Kultz, 2015).

Humpback grouper classified to stenohalin which settled on certain water (aquatic water), toleranted to changes in low salinity. It was different from Euryhaline fish, that is fish migration having a high tolerance to changes in salinity (Willmer, et al, 2004). Time required for the stress recovery of fish is determined by stressor or the trigger of stress (Rinen, 2004). Range of sanility from first habitat with new habitat determined the success of the adabtable fish (Purcell, 2008). The stressor of the study was range of 26 and speed of the decrease in salinity, the higher range and the faster the decrease in salinity, the higher range of stress. 
On optimal medium salinity, osmoregulation activity was low, whereas the outside salinity, the optimal osmoregulation activity was increasing so that the amount of energy required was also increasing (Rachmawati, 2012). Treatment with the decrease in salinity quickyl, required more

energy to adapt causing energy reserve was limited making fish become weak and susceptible to disease then died (Oktarina, 2009).

\section{B. The Rate Of Growth}

Growth rate data were analyzed with Anova $(\mathrm{P} \leq 0.05)$, result showed that there was significant different, then it was continued to Duncan Test $(P \leq 0.05)$, result showed $\mathrm{A}_{0.5}$ was not significant different from $\mathrm{A}_{0}$ (control) but it was significant different from $A_{1} A_{1.5}$ and $A_{2}$ as seen on Table 2.

Table 2. Average Growth Rate (\%)

\begin{tabular}{cc}
\hline Treatment & Rate Of Growth \\
\hline A0 & $0,62 \pm 0,82^{\mathrm{a}}$ \\
A0,5 & $0,60 \pm 1,00^{\mathrm{a}}$ \\
A1 & $0,50 \pm 2,76^{\mathrm{b}}$ \\
A1.5 & $0,35 \pm 4,04^{\mathrm{c}}$ \\
A2 & $0,14 \pm 5,68^{\mathrm{d}}$
\end{tabular}

From Table 2, it was clear, treatment $\mathrm{A}_{0.5}$ ( the decrease in salinity $0.5 \mathrm{ppt} /$ day) was the highest rate of growth. This was caused by the slower decrease in salinity of acclimatization into fresh water, the lower level of adaptation, and instead of the faster decrease in salinity of acclimatization into fresh water, the higher level of adaptation. Adaptation to extreme environmental change quickly required a lot of energy, including energy for recovery so that energy for the growth was decreasing (Oktarina, 2009). Adaptation carrying out was related with osmoregulation activity. If energy for osmoregulation activity was increasing so energy for the growth was decreasing so that it was decreasing the growth rate (Rachmawati, 2012).

\section{Conclusion}

Humpback groupers fish (Cromileptes altivelis) are able to live and cultivated in brackish water using salinity $4 \mathrm{ppt}$ (mesohalin) through acclimatization with the decrease in salinity $0.5 \mathrm{ppt} /$ day. The decrease in salinity $0.5 \mathrm{ppt} /$ day does not affect the growth rate.

\section{Acknowledgements}

Thank you addressed to the Directorate of Research and Community Service of the Directorate General of Research and Development of Ministry of Research, Technology, and Higher Education that has been funded the research.

\section{References}

Agustin,R. et al, 2014, Feed Conversion, Rate of Growth, Survival, and Bacterial Populations of Fish Seed Cork (Channa srtiata) havng been given feed with the addition of Probiotics, Journal Aquaculture Swamp Indonesia, 2 (1): 55-66

Anggoro, S. et al, 2013, Domesticated Tiger Grouper (Epinephelus fuscoguttatus), Journal Of Management Of Aquatic Resorces, Volume 2 (3):119-127

Irianto, A. 2005. Teleostei Fish Pathology. Gajah Mada University Press, Yogyakarta.

Kultz, D. 2015, Physiological Mechanisms used by Fish to Cope with Salinity Stress, Journal of Experimental Biology 218:1907-1914

Maryadi, 2008, Acclimatization of Tiger Shrimp (Penaeus monodon) Seeds in an effort to Cultivating an environment outside of his life: a case in Lamongan, Central Agency for Competitiveness Policy assessment and application of technology, Jakarta, m. tech. Ling, vol. 4 (2):143152. 
Oktarina, R.M., 2009, influence the frequency of soaking in fresh water on performance growth of Humpback Grouper (Cromileptes altivels), (Thesis), Faculty of fisheries and marine sciences, Institut Pertanian Bogor

Subiyakto. S. \& Cahyaningsih. S. 2003. Seeding Grouper Household Scale, Agromedia Pustaka, Jakarta.

Purcell, M.K. et al, 2008, Adaptation as a potential response to sea-level rise: a genetic basis for salinity tolerance in populations of a coastal marsh fish, evolution of Aplications, 1 (1): 155 160.
Rachmawati, D. 2012, Tiger Snail Domestication (Babylonia spirata L.) Through the optimization of Media and feed (Dissertation). Coastal Resources Management Doctoral Program. Graduate Program. University Of Diponegoro. Semarang. Rinen, P.H., 2004, Effects of abrupt cold shock on stress responses and recovery in brown trout exhausted by swimming, Journal of Fish Biology 64:1015 - 1026

Willmer, P. et al, 2005, Environmental Physiology of Animals ${ }^{2}$ nd, Wiley Blackwell, London. 